\title{
THERAPEUTIC USE OF HUMAN EMBRYONIC STEM CELLS
}

\author{
Justo Aznar ${ }^{1}$, Pedro Navarro-Illana ${ }^{2}$
}

Human embryonic stem cells (hESC) are pluripotent cells derived from the blastocyst inner cell mass, a 5-6 day-old embryo. In order to obtain these cells, that early human embryo needs to be destroyed, causing objective ethical problems.

The first hESC lines were produced by Thomson et al. in 1998(1). Since, they have been widely used for experimental purposes; however, their therapeutic use is much more reduced.

In fact, ClinicalTrials.org states that 144,300 clinical trials have been carried out worldwide(2). 4451 of those, with adult stem cells, and only 15 with hESC (Table 1).

Table 1. Clinical trials now under way about human embryonic stem cells. According to the website clinicaltrials.org (accessed in October 28, 2013).

\begin{tabular}{|c|c|c|}
\hline No & Status & Trial \\
\hline 1 & Not yet recruiting & $\begin{array}{l}\text { A Study Of Implantation Of Human Embryonic Stem Cell Derived Retinal Pig- } \\
\text { ment Epithelium In Subjects With Acute Wet Age Related MacularDegeneration } \\
\text { And Recent Rapid Vision Decline. }\end{array}$ \\
\hline 2 & Recruiting & $\begin{array}{l}\text { A Phase I/IIa, Open-Label, Single-Center, Prospective Study to Determine the } \\
\text { Safety and Tolerability of Sub-retinal Transplantation of Human Embryonic Stem } \\
\text { Cell Derived Retinal Pigmented Epithelial (MA09-hRPE) Cells in Patients With } \\
\text { Advanced Dry Age-related Macular Degeneration (AMD). }\end{array}$ \\
\hline 3 & Recruiting & $\begin{array}{l}\text { Safety and Tolerability of Sub-retinal Transplantation of Human Em- } \\
\text { bryonic Stem Cell Derived Retinal Pigmented Epithelial (hESC-RPE) Cells in } \\
\text { Patients With Stargardt's Macular Dystrophy (SMD). }\end{array}$ \\
\hline 4 & Recruiting & The Derivation of Human Embryonic Stem Cell Lines From PGD Embryos. \\
\hline 5 & Recruiting & $\begin{array}{l}\text { Safety and Tolerability of Sub-retinal Transplantation of hESC Derived RPE (MA09- } \\
\text { hRPE) Cells in Patients With Advanced Dry Age Related Macular Degeneration. }\end{array}$ \\
\hline 6 & Recruiting & Derivation of New Human Embryonic Stem Cell Lines Lines for Clinical Use. \\
\hline 7 & Recruiting & $\begin{array}{l}\text { Sub-retinal Transplantation of hESC Derived RPE (MA09-hRPE) Cells in Pa- } \\
\text { tients With Stargardt's Macular Dystrophy. }\end{array}$ \\
\hline 8 & Recruiting & $\begin{array}{l}\text { Safety and Tolerability of MA09-hRPE Cells in Patients With Stargardt's Macular } \\
\text { Dystrophy (SMD). }\end{array}$ \\
\hline 9 & Unknown $\dagger$ & $\begin{array}{l}\text { Derivation of New Human Embryonic Stem Cell Lines: Identification of Instructive } \\
\text { Factors for Germ Cells Development. }\end{array}$ \\
\hline 10 & Active, not recruiting & $\begin{array}{l}\text { Development of iPS From Donated Somatic Cells of Patients With Neurologi- } \\
\text { cal Diseases. }\end{array}$ \\
\hline 11 & Completed & $\begin{array}{l}\text { The Transendocardial Autologous Cells (hMSC or hBMC) in Ischemic Heart } \\
\text { Failure Trial (TAC-HFT). }\end{array}$ \\
\hline
\end{tabular}

${ }^{1}$ Director of the Institute of Life Sciences, Catholic University of Valencia,Valencia, Spain

Correspondence: justo.aznar@ucv.es

${ }^{2}$ Dean of Nursing Faculty. Catholic University of Valencia “San Vicente Mártir”, Valencia, Spain 


\begin{tabular}{|l|l|l|}
\hline 12 & Terminated & $\begin{array}{l}\text { Skin and Blood Research Samples From Healthy Volunteers and Patients With He- } \\
\text { matologic Diseases. }\end{array}$ \\
\hline 13 & Completed & $\begin{array}{l}\text { The Percutaneous Stem Cell Injection Delivery Effects on Neomyogenesis Pilot } \\
\text { Study (The POSEIDON-Pilot Study). }\end{array}$ \\
\hline 14 & Recruiting & Stem Cell Educator Therapy in Type 1 Diabetes. \\
\hline 15 & Active, not recruiting & $\begin{array}{l}\text { Evaluation of Circulating Levels of Adult Stem Cells in the Peripheral Blood of } \\
\text { Patients With Acute Decompensated Heart Failure and Following Stabilization, in } \\
\text { Comparison With Healthy Volunteers. }\end{array}$ \\
\hline
\end{tabular}

In order to ascertain that those 15 clinical trials had actually used hESC with therapeutic purposes, we analyzed them to see whether there was objective data.

We previously established that the aim of trials 10 and 12 was to produce induced pluripotent stem cells (iPS) or to assess their action. In trial 13, they used autologous mesenchymal cells; in trial 14, umbilical cord cells and, in trial 15, only adult stem cells circulating levels were assessed.

In trials 1 and 9, hESC were used, however in trial 1 there had not been patient recruitment yet. In trial 2, the first data would not be obtained until February 2016; in trial 3 until January 2014 and, in trial 8, until August 2014. Clinical trials 4, 6 and 9 were aimed at improving the obtaining technique of the embryonic stem cells lines.

Only trials 5 and 7 had the objective to assess the hESC therapeutic use and provided a specific result.

Preliminary data of these two trials has been published in The Lancet(3). In trial 5 (NCT01345006), they assessed the safety and tolerability of retinal transplantation of hESC-derived retinal pigmented epithelium (hESCP-RPE) on a patient with Stargardt macular dystrophy and on a patient with dry age-related macular degeneration, in trial 7 (NCT 01344993). The visual acuity improved from hand motions to 20/800 in the eye study of the patient with Stargardt macular dystrophy and vision also seemed to improve in the patient with dry age-related macular degeneration (from 21 ETDRS letters to 28$)$.

Thus, can anything be concluded from the use of hESC for therapeutic purposes only from the data of these two patients? In our opinion, there is no medical evidence that justifies their use.

\section{References}

1. Thomson JA, Itskovitz-Eldor J, Shapiro SS, Waknitz MA, Swiergiel JJ, Marshall VS, et al. Embryonic stem cell lines derived from human blastocysts. Science 1998; 282(5391): 1145-1147. Erratum in: Science 1998 Dec 4; 282(5395): 1827. Clinicaltrial.org (Accessed October 28, 2013).

2. Schwartz SD, Hubschman JP, Heilwell G, Franco-Cardenas V, Pan CK, Ostrick RM, et al. Embryonic stem cell trials for macular degeneration: a preliminary report. Lancet 2012; 379(9817): 713-720. 